\title{
Applying Built-Up and Bare-Soil Indices from Landsat 8 to Cities in Dry Climates
}

\author{
Azad Rasul 1,2,*(D) , Heiko Balzter 1,3 (i), Gaylan R. Faqe Ibrahim ${ }^{2}$ (D) , Hasan M. Hameed 2 (D), \\ James Wheeler ${ }^{1}$, Bashir Adamu ${ }^{1,4}$, Sa'ad Ibrahim ${ }^{1,5}$ and Peshawa M. Najmaddin 1,6 \\ 1 Centre for Landscape and Climate Research, School of Geography, Geology and the Environment, \\ University of Leicester, University Road, Leicester LE1 7RH, UK; hb91@le.ac.uk (H.B.); \\ jemw3@le.ac.uk (J.W.); ba108@alumni.le.ac.uk (B.A.); saadarg1@yahoo.com (S.I.); \\ peshawa.najmaddin@gmail.com or pmn7@le.ac.uk (P.M.N.) \\ 2 Department of Geography, Faculty of Arts, Soran University, Soran 44008, Iraq; \\ gailan.faqe@soran.edu.iq (G.R.F.I.); hasan.hamid@soran.edu.iq (H.M.H.) \\ 3 National Centre for Earth Observation, University of Leicester, University Road, Leicester LE1 7RH, UK \\ 4 Department of Geography, Modibbo Adama University of Technology, Yola P.M.B. 2076, Nigeria \\ 5 Department of Geography, Adamu Augie College of Education, Argungu 861231, Nigeria \\ 6 Department of Soil and Water Science, College of Agricultural, University of Sulaimani, \\ Sulaimania 46001, Iraq \\ * Correspondence: aor4@alumni.le.ac.uk or azad977@gmail.com or azad.rasul@soran.edu.iq; \\ Tel.: +964-(0)-750-735-8574
}

Received: 7 June 2018; Accepted: 2 July 2018; Published: 4 July 2018

\begin{abstract}
Arid and semi-arid regions have different spectral characteristics from other climatic regions. Therefore, appropriate remotely sensed indicators of land use and land cover types need to be defined for arid and semi-arid lands, as indices developed for other climatic regions may not give plausible results in arid and semi-arid regions. For instance, the normalized difference built-up index (NDBI) and normalized difference bareness index (NDBaI) are unable to distinguish between built-up areas and bare and dry soil that surrounds many cities in dry climates. This paper proposes the application of two newly developed indices, the dry built-up index (DBI) and dry bare-soil index (DBSI) to map built-up and bare areas in a dry climate from Landsat 8 . The developed DBI and DBSI were applied to map urban areas and bare soil in the city of Erbil, Iraq. The results show an overall classification accuracy of $93 \%(\kappa=0.86)$ and $92 \%(\kappa=0.84)$ for DBI and DBSI, respectively. The results indicate the suitability of the proposed indices to discriminate between urban areas and bare soil in arid and semi-arid climates.
\end{abstract}

Keywords: dry built-up index (DBI); dry bare-soil index (DBSI); dry climates; land use land cover; Erbil; remote sensing; indices; Landsat 8

\section{Introduction}

In recent decades, different remote sensing methods such as aerial photography and satellite imaging have become widely available as a source of data for mapping and monitoring land use and land cover. Due to rapid urbanization, land cover around many of the world's urban areas changes more quickly than ever before. The data obtained from remote sensing platforms provide up-to-date information and a general view of landscape characteristics and changes in urban areas [1].

Bare land, whether seasonal or permanently bare, plays an important role in many ecosystems, for instance, as a source of Aeolian deposits during sandstorms. However, the differentiation of base land from urban areas in arid and semi-arid environments has often proven difficult. There are different 
methods and techniques that have been used to identify urban areas from other land cover types, for example, classification into urban, rural and other classes. Night-light satellite data can also be used to distinguish between urban and non-urban areas [2]. The Normalized Difference Built-up Index (NDBI) was proposed in 2003 as a new method which automatically maps built-up areas. This method was first applied in practice to extract data for a built-up area of Nanjing city in eastern China [1]. Although the NDBI index was able to distinguish between built-up and vegetated or green and wet surroundings for the city of Nanjing, it was not successful in distinguishing between built-up and other land cover such as bare and dry soil that surround the city, due to the overlapping spectral reflectance for these land cover types [3]. Although several techniques to observe land use and land cover have been developed, an evaluation of the performance and accuracy of these techniques in dry climate regions is rarely available. We have conducted several tests using NDBI and NDBaI derived from Landsat TM, ETM+ and OLI for LULC of Erbil. The NDBI results produced a high value for bare soil; in contrast, NDBaI produced a high value for built-up. Generally, NDBI is more efficient in places where the NDVI value is greater than 0 [1]. Therefore, this method is not suitable for cities located in dry climates (Table 1).

Table 1. Average and standard deviation of DBI, NDBI, UI and EBBI of the city at $10 \mathrm{~km}$ buffer outside the city.

\begin{tabular}{cccccc}
\hline Indices & Mean (City) & SD (City) & Mean $\mathbf{( 1 0} \mathbf{~ k m ~ B u f f e r )}$ & SD (10 km Buffer) & Difference (City-Buffer) \\
\hline DBI & 0.743 & 0.083 & 0.653 & 0.056 & 0.090 \\
NDBI & 0.186 & 0.052 & 0.214 & 0.039 & -0.028 \\
UI & 0.070 & 0.066 & 0.085 & 0.082 & -0.015 \\
EBBI & 0.303 & 0.223 & 0.567 & 0.245 & -0.264 \\
\hline
\end{tabular}

Spectral indices are a good approach to distinguish land cover types [4]. Chen [5] proposed a bare soil index (BI) primarily for bare land extraction from satellite data. The normalized difference soil index (NDSI) has been used to detect signature changes in un-mixing coastal marsh from satellite images [6]. A normalized difference bareness index (NDBaI) was proposed by Chen et al. [4] to distinguish bare land from other land use classes using Landsat data. As the output of this method showed a higher NDBaI value of built-up areas than bare land, this index appears not to be appropriate for use in cities in semi-arid environments. As-syakur et al. [7] proposed an enhanced built-up and bareness index (EBBI) and provided a case study of Denpasar city in Bali, Indonesia, with $90.5 \%$ overall accuracy of bare land detection [8]. A normalized difference bare land index (NBLI) and unsupervised classification was used by Li et al. [8] to automatically map bare land from Landsat images. Bare soil indices, in particular most commonly NDBaI, are frequently used in humid regions with high accuracy while bare soil in dry areas requires improved indices.

Impervious surface materials and bare soil are both parts of the land surface [9]. Sub-pixel and layered classification was proposed by Ji and Jensen [10] for coastal and urban environments. This method was later modified by Flanagan and Civco [11] by using artificial neutral networks to retrieve the impervious surface fraction. Lu and Weng [12] developed a new method for urban land use classification based on the combined use of impervious surface and population density. The Urban Index (UI) [13] performs better in the identification of urban areas but is unable to distinguish bare land and built-up areas accurately [14]. Wu and Murry [15] employed a linear mixture pixel analysis (LMPA) to extract impervious distribution. Similarly, Xu [16] proposed a normalized impervious surface index (NDISI) for the estimation of impervious surfaces. It was demonstrated that NDISI can extract impervious surfaces efficiently. Based on NDBI, a continuous built-up index $\left(\mathrm{BU}_{\mathcal{c}}\right)$ was developed by He et al. [3]. Stathakis et al. [17] suggested a vegetation index built-up index (VIBI) to segment urban areas efficiently. Deng and $\mathrm{Wu}$ [18] proposed a biophysical composition index (BCI). Land in arid and semi-arid regions has different spectral characteristics from other climatic regions. Therefore, appropriate remotely sensed indicators of land use and land cover types need to be defined 
for arid and semi-arid lands, as indices developed for other climatic regions may not give plausible results in those regions.

In 2013, Landsat 8 was launched with two sensors, the Operational Land Imager (OLI) and the Thermal Infrared Sensor (TIRS). To monitor long-term land cover and land use change, Landsat data are crucial. To minimize atmospheric absorption features, the width of several OLI bands in Landsat 8 was enhanced [19]. In 2014, Bhatti and Tripathi proposed a built-up area extraction method (BAEM), and similarly, Zhou et al. used a built-up and bare-land index (BBI) to extract built-up and bare soil from Landsat 8 [20,21]. Piyoosh and Ghosh [22] developed a normalized ratio urban index (NRUI) and modified normalized difference soil index (MNDSI) to distinguish between urban areas and soil from Landsat 8.

The reviewed literature on spectral indices leads us to conclude that these indices have not entirely successfully addressed the confusion between impervious surface and bare soil $[18,23]$. Hence, this study focusses on identifying appropriate remotely sensed indices for arid and semi-arid regions derived from Landsat 8 data. It addresses the difference between bare soil and built-up classes that are inherent in other indices for mapping land use land cover classes in cities in dry climates in anticipation that this will provide better information than that obtainable from previously published spectral indices. Erbil city in Iraq was selected for this research and a Landsat 8 image was obtained in the dry season for examining the effectiveness of the proposed techniques. The objective of the current study was to determine the accuracy of the newly proposed indices (dry built-up index (DBI) and dry bare-soil index (DBSI)) in mapping built-up and bare soil areas in dry climate from Landsat 8 .

\section{Study Area}

Erbil is located $412 \mathrm{~m}$ above sea level within $36^{\circ} 08^{\prime} \mathrm{N}-36^{\circ} 14^{\prime} \mathrm{N}$ and $43^{\circ} 57^{\prime} \mathrm{E}-44^{\circ} 03^{\prime} \mathrm{E}$ [24]. The study area is located in the central part of northern Iraq serving as the capital of Kurdistan region (Figure 1). The population of the Erbil Governorate was estimated to be around 1,500,000 inhabitants in 2015 [25].

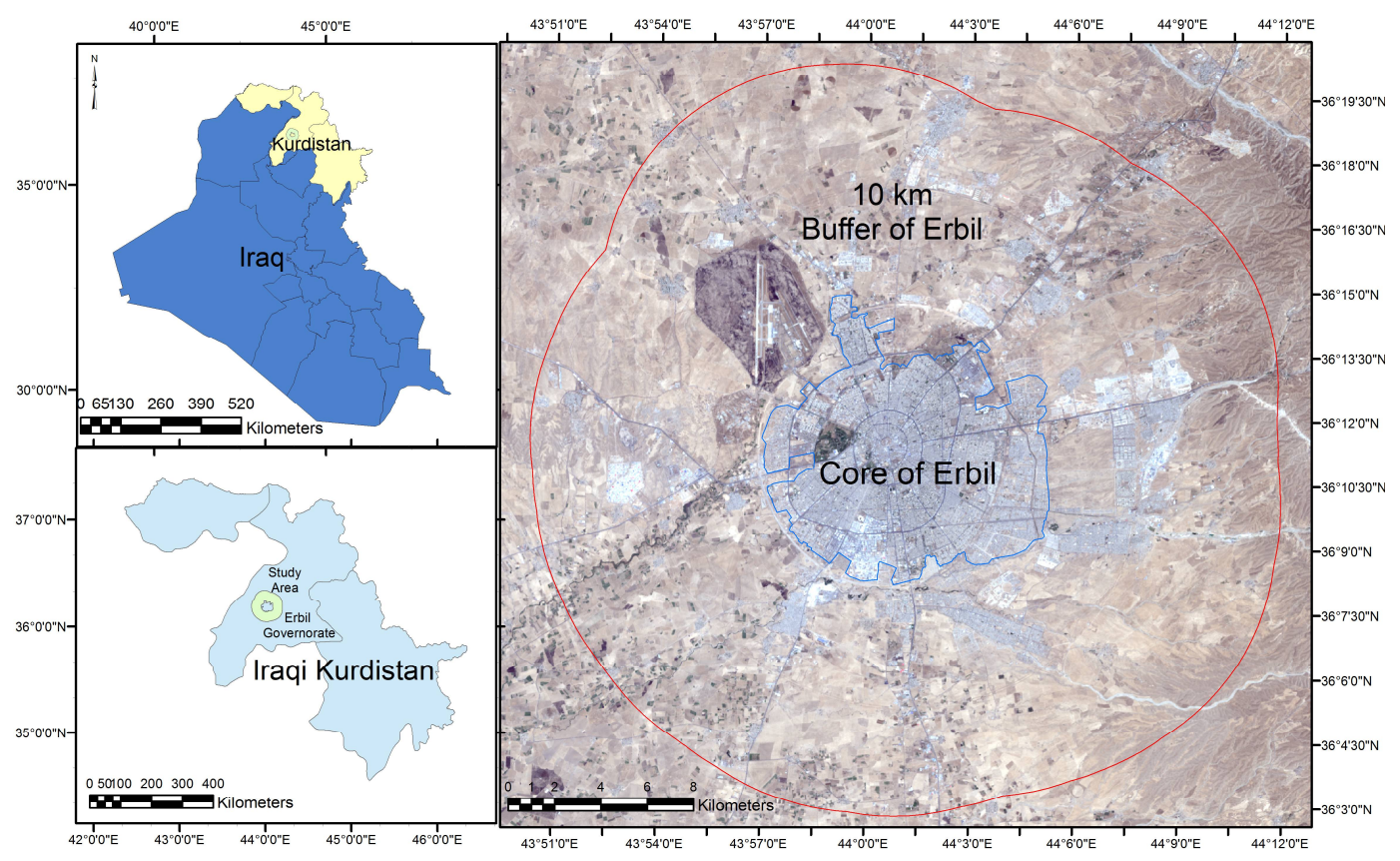

Figure 1. Map of Iraq, the Kurdistan Region and true colour Landsat image of the study area.

The city has a semi-arid continental climate, a rainy cool winter and dry and warm summer. The seasonal distribution of the precipitation in the study area varies and falls mostly as rain in winter and autumn [26]. The average annual precipitation is $380.26 \pm 108.88 \mathrm{~mm}$. The annual air temperature is $22^{\circ} \mathrm{C}$, and July and August are the hottest months of the year [24]. The dominant land use type in the city is residential land use and concrete blocks are the main material for buildings. In general, winter 
grains are the most common form of land cultivation in the area and depend on rainfall; therefore, in the summer, the majority of croplands are dry [27,28].

\section{Materials and Methods}

\subsection{Data}

A Landsat 8 image from 1 July 2013 on path 139 and row 35 was used in this research. The data were provided as level L1T data captured under clear atmospheric conditions (cloud coverage $=0.01 \%$ ) in the dry season. The image is in UTM projection (zone $38 \mathrm{~N}$ ) and was retrieved from the United States Geological Survey (USGS), Earth Explorer website [29].

\subsection{Methodology}

To overcome the limitations in the aforementioned indices we used Blue, TIR1, SWIR1 and Green bands to separate built-up and bare areas in the dry climate of Iraq from Landsat 8 and to assess the performance of these indices using accuracy assessment.

\subsubsection{Dry Built-Up Index}

In general, all the four classes in the study area (bare soil: black colour, built-up: red colour, water: blue colour and green area: green colour) have their highest digital number (DN) in band 10; bare land as the first, built-up class as the second highest DN in this band (Figure 2). In contrast, the lowest DN of all classes is located in band 6 (SWIR-1). In most bands, the DN of barren land is higher than that of built-up areas; only in bands 1 and 2 is the spectral signature of the built-up class higher than that of bare land. The DN values of water is lower than the DN of all other classes across all bands.

Spectral disparity of built-up and bareness classes is low in the Blue band; however, it is large in the TIR1 band (Figure 2). The urban areas had higher blue reflectance than bare soil as a result of the type of building materials, mainly concrete, used for roof surfaces and walls. After testing Landsat 8 bands, we found that these classes can be better distinguished in Blue and TIR1 bands in the study area, thus the proposed equation for built-up area in dry climate is:

$$
D B I=\frac{\rho_{\text {Blue }}-\rho_{\text {TIR } 1}}{\rho_{\text {Blue }}+\rho_{\text {TIR1 }}}-N D V I
$$

where $\rho_{\text {Blue }}=$ band $2, \rho_{\text {TIR1 }}=$ band 10 .

A mask was applied to water surface pixels using water index NDWI.

$$
\begin{gathered}
N D W I=\frac{\rho_{\text {Green }}-\rho_{\text {NIR }}}{\rho_{\text {Green }}+\rho_{\text {NIR }}} \\
N D V I=\frac{\rho_{N I R}-\rho_{R E D}}{\rho_{N I R}+\rho_{R E D}}
\end{gathered}
$$

where NDVI is normalized difference vegetation index, $\rho_{N I R}$ is the surface reflectance of band 5 and $\rho_{R E D}$ is the surface reflectance of band 4 in Landsat 8 . The reason for subtracting the DBI layer from the NDVI values is that built-up areas can be identified better $[3,20,30]$. Through this step, DBI values of green vegetation will decrease and the features with higher DBI values but lower NDVI values will be enhanced.

The DBI values can be between -2 to +2 and the higher numbers represent more built-up areas. An appropriate threshold of the built-up class from the output of the equation can be used for mapping built-up and non-built-up areas. A test was conducted on the number of built-up pixels by selecting values 0.72 and higher as built-up for the study area while lower than this threshold as non-built up class. Note that the threshold of DBI and DBSI to extract built-up and bare-soil may vary based on the study site. 


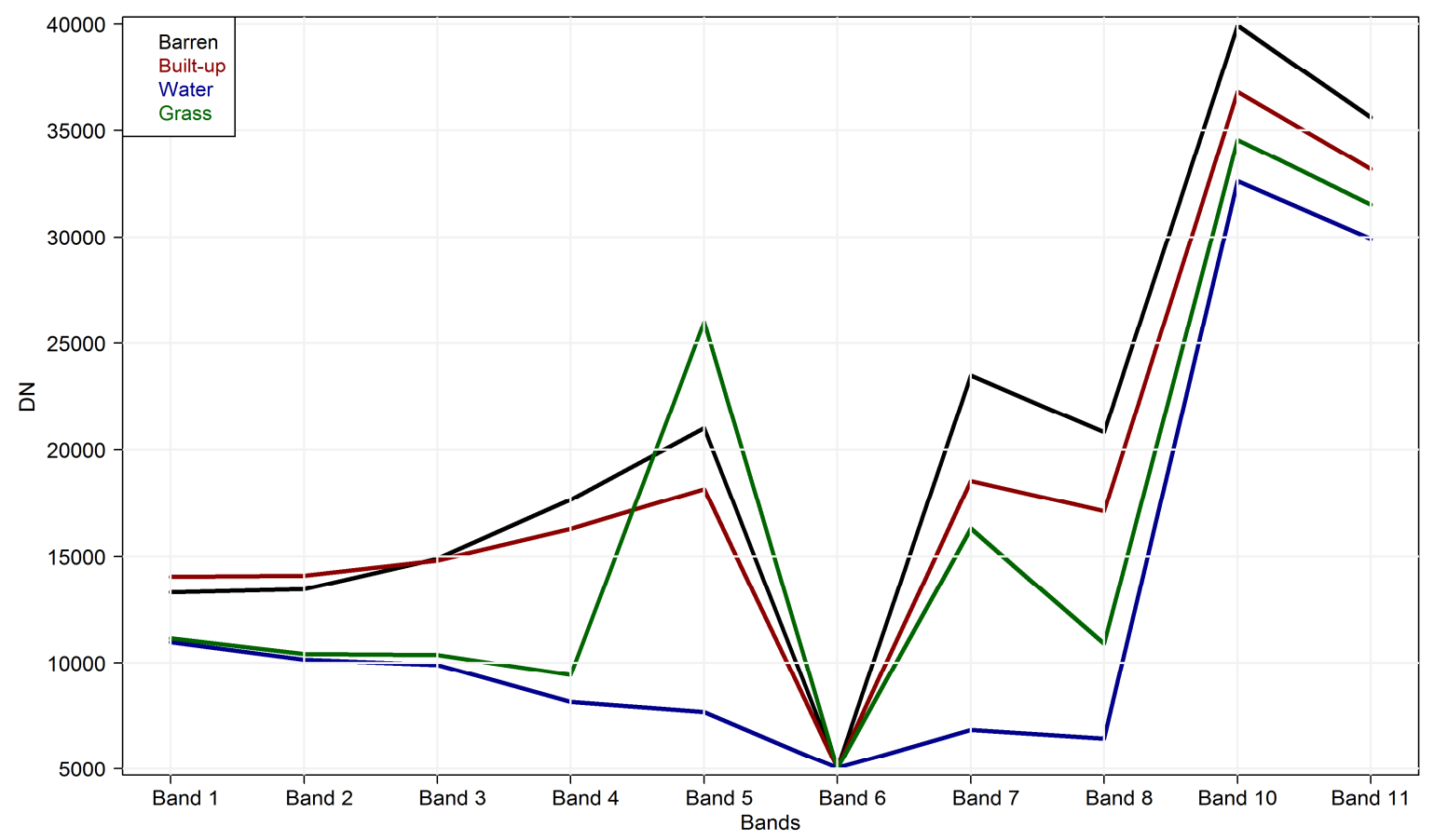

Figure 2. Mean spectral profiles for four typical land covers in the study area.

\subsubsection{Dry Bareness Index}

The result of testing common bare soil index (NDBaI) indicated that bare soil has lower mean NDBaI than mean NDBaI of built-up areas, meaning that this index was not able to accurately detect bare soil in the study area. DN of bareness and built-up classes is low in band 6 and high in band 3 . Inspection of the Landsat 8 bands suggested that differentiation of these classes could be done based on spectral values in the SWIR1 and Green bands. In these bands, generally the DN of bare land is slightly higher than the DN of the built-up class. Thus, the proposed equation for bareness area in dry climate is the inverse of the Modified Normalized Difference Water Index (MNDWI; [31]):

$$
D B S I=\frac{\rho_{\text {SWIR1 }}-\rho_{\text {Green }}}{\rho_{\text {SWIR1 }}+\rho_{\text {Green }}}-N D V I
$$

where $\rho_{\text {SWIR1 }}=$ the surface reflectance of band $6, \rho_{\text {Green }}=$ the surface reflectance of band 3 in Landsat 8 .

The DBSI values can be between -2 to +2 , and higher numbers represent more bare soil. An appropriate threshold for the bare soil class can be used for mapping bare soil and non-bare soil areas. Based on a test carried out with a sample of bare soil pixels, a DBSI value 0.26 and higher was delineated as bare soil for the study area, and areas with lower values were delineated as other classes.

\subsubsection{Accuracy Assessment}

In order to assess the accuracy of classified images based of the DBI and DBSI indices, 300 points were randomly selected for each class using ArcGIS (Figure 3). Each reference point represents one pixel on the classified image. It means overall, 300 pixels were randomly considered. For DBI, 150 points were selected for the built-up class and 150 points for the non-built-up class. A similar procedure was repeated for DBSI, with 150 points for bare soil and 150 points for other classes. Afterwards, these pixels were compared with high-resolution satellite images from the online ArcGIS 10.3 basemaps (Image source: Esri, DigitalGlobe, GeoEye, i-cubed, Earthstar Geographics, CNES/Airbus DS, USDA, USGS, AEX, Getmapping, Aerogird, IGN, IGP, swisstopo, and the GIS User Community). 


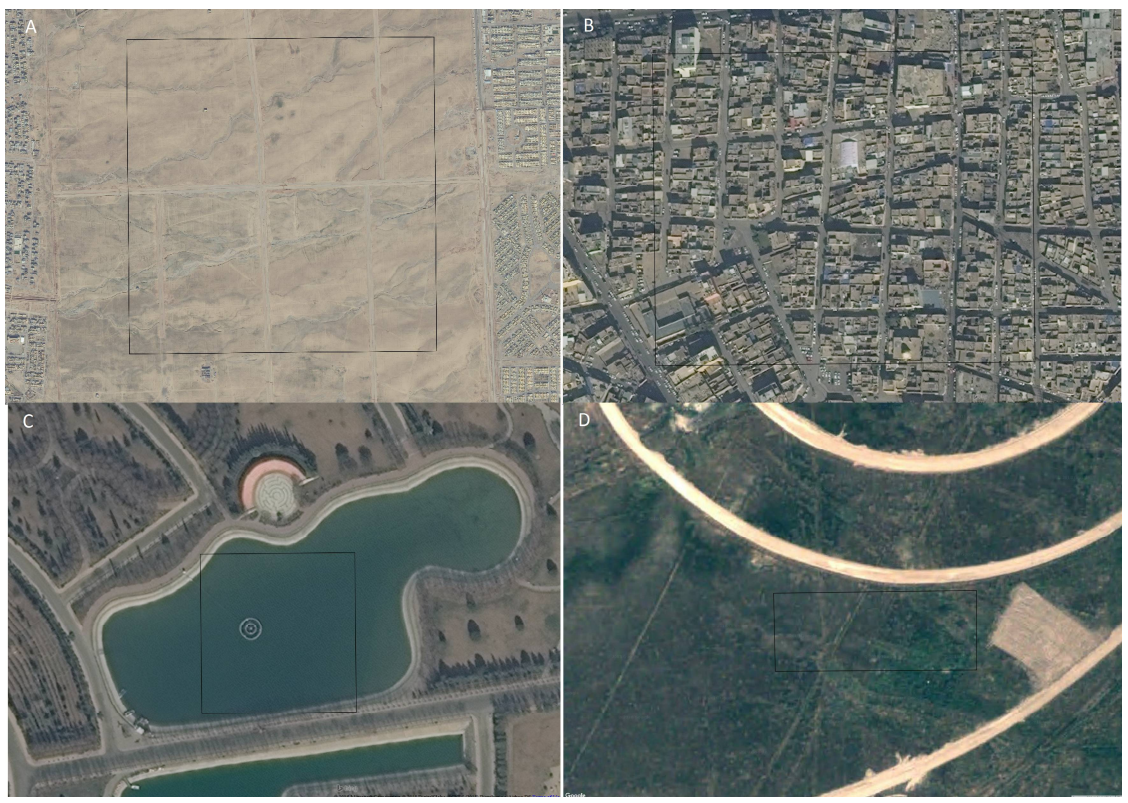

Figure 3. Samples of selected land covers in Erbil. Number of pixels: Bare-soil $=4556$, Built-up $=99$, Grass $=10$, Water $=9$.

\section{Results}

\subsection{Mapping Built-Up Areas Using the Dry Built-Up Index}

The DBI (Figure 4) was calculated from Equation (1) for the study area. Figure 4 illustrates that low DBI is present outside the city border. In contrast, high DBI is inside the city border and within the $100 \mathrm{~m}$ Street. Average DBI within the city borders is 0.74 while average DBI outside the city borders is 0.65 (Table 1). Figures 5 and 6 illustrate the comparison between DBI and NDBI. Figure 5 showed that the difference between the built up and bare-soil is higher in DBI than for NDBI and UI. DBI built-up land has the highest value based on the purpose of highlighting class by the index while in NDBI, UI and EBBI, bare-soil has the highest value.

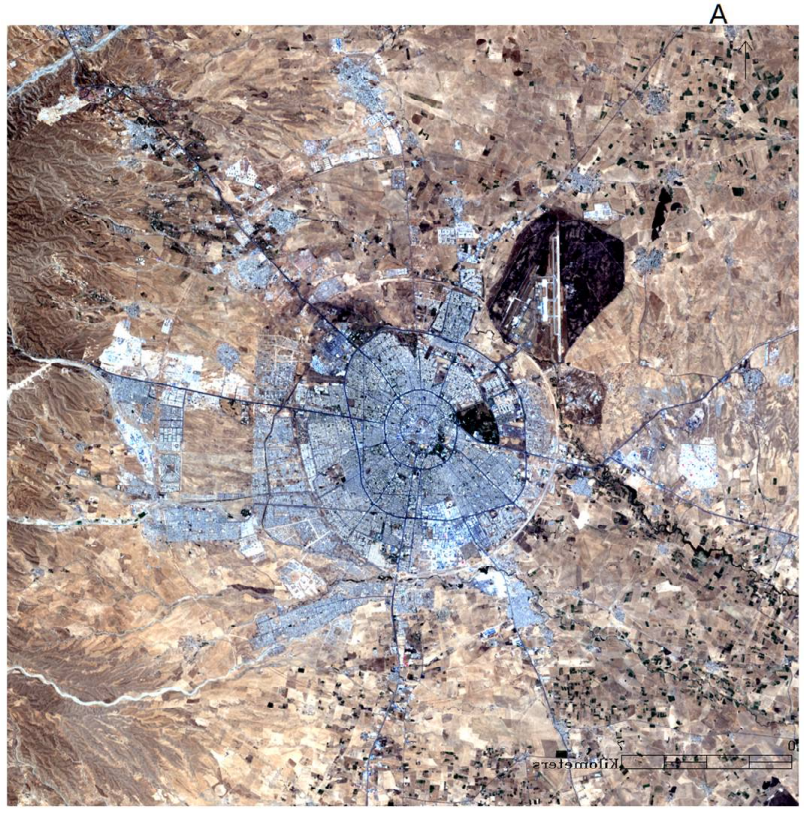

Figure 4. Cont. 

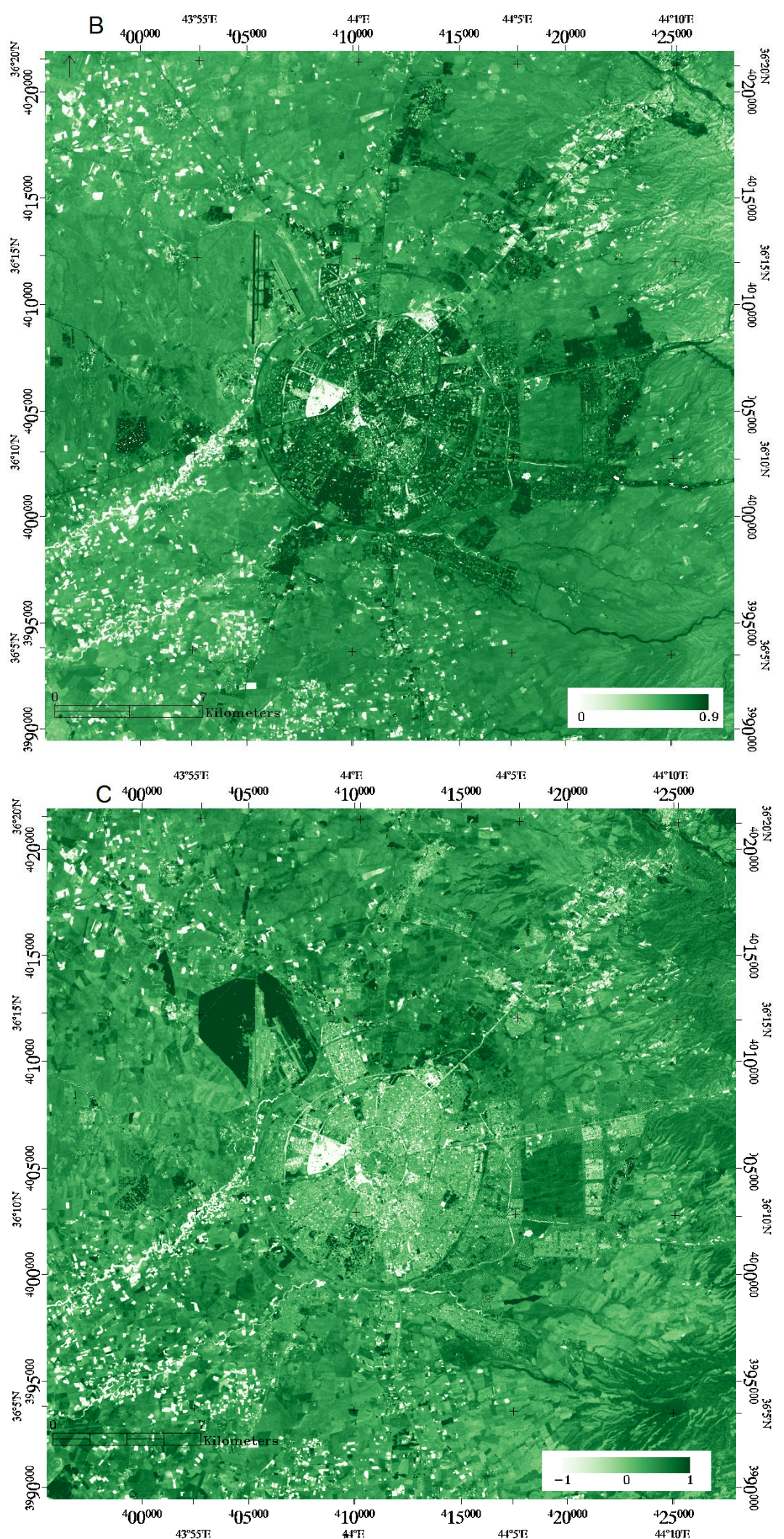

Figure 4. Dry Built-up Index of Erbil city from Landsat 8 image of 1 July 2013. (A) Red, Green, Blue band, (B) DBI, (C) NDBI. 

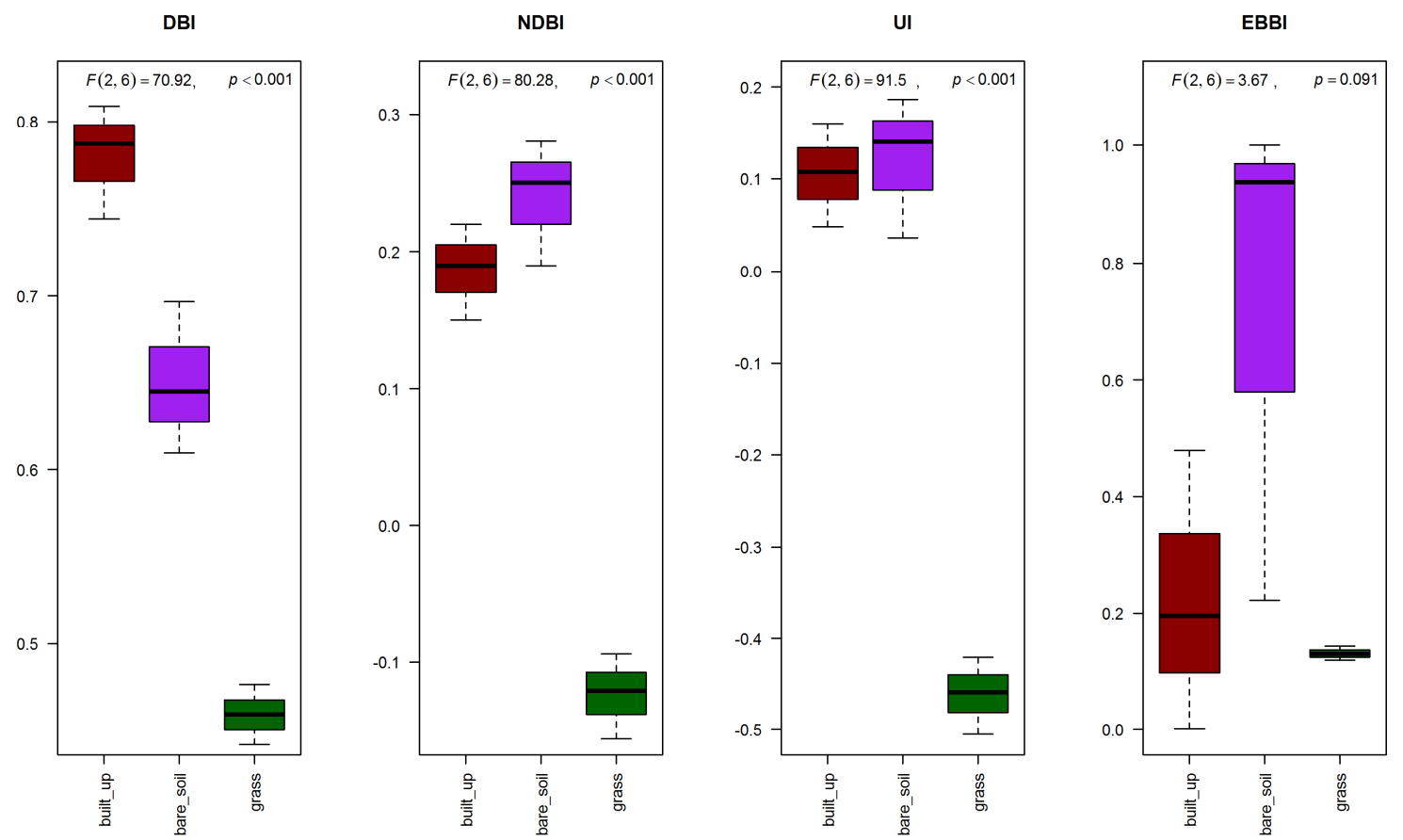

Figure 5. Comparison of three class samples between DBI and NDBI, UI, EBBI of the study area.

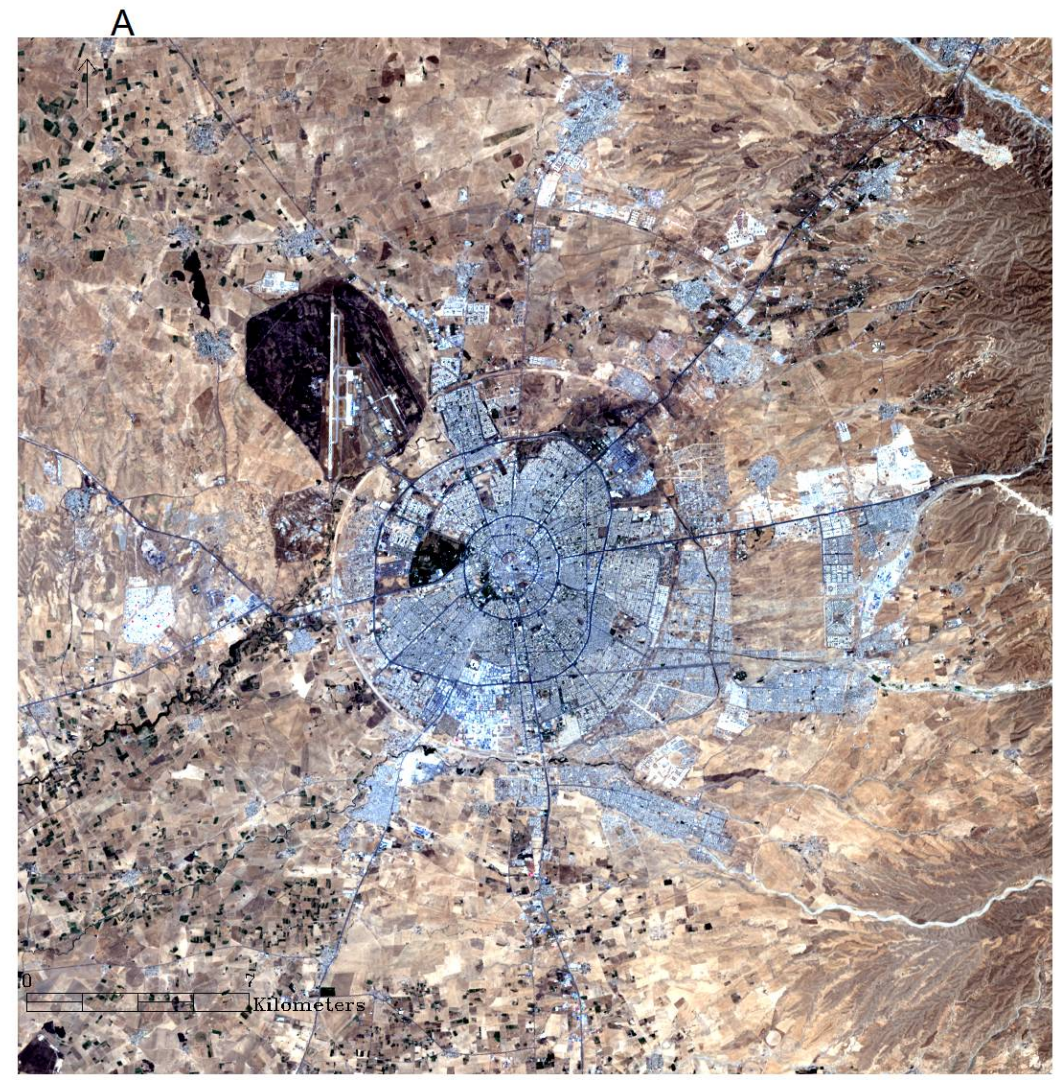

Figure 6. Cont. 

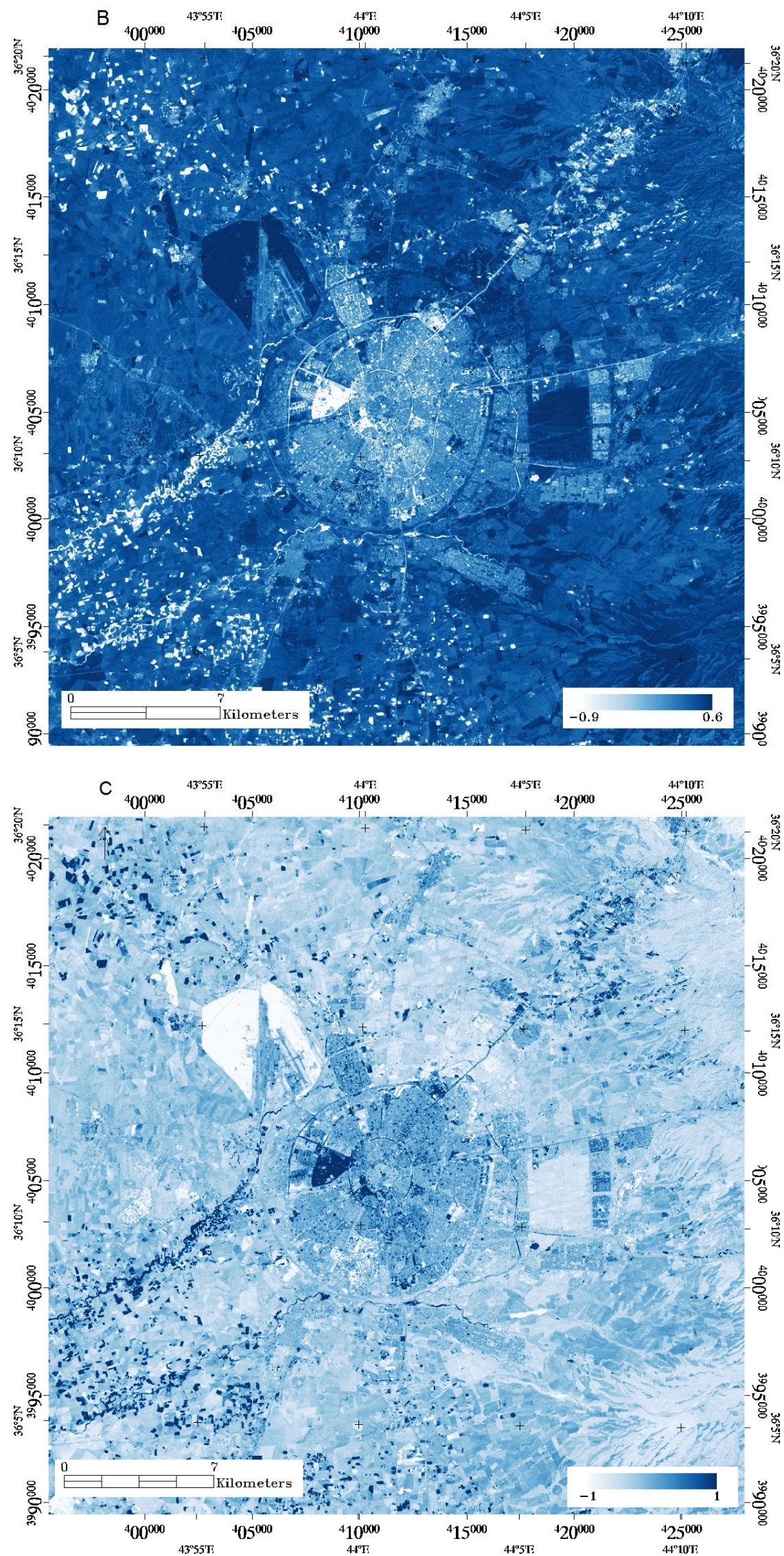

Figure 6. Dry Bare-soil Index of Erbil city from Landsat 8 image of 1 July 2013. (A) Red, Green, Blue band, (B) DBSI, (C) NDBaI. 


\subsection{Mapping Bareness Areas Using Dry Bare-Soil Index}

The DBSI map (Figure 5) was produced from Equation (4) for Erbil city. Bare soil includes both bare areas and seasonally bare farmland. Figure 5 illustrates that high DBSI is found outside the city borders, for instance, in the north and north-west of the study area. In contrast, low DBSI is seen inside the city borders and inside the $100 \mathrm{~m}$ street. The average DBSI within the city borders is 0.14 and DBSI outside the city borders is 0.21 (Table 2). This result confirms that the proposed index is able to delineate bare soil with a higher value of DBSI compared to other classes such as built-up areas. Figures 6 and 7 show the comparison between DBSI and NDBaI.
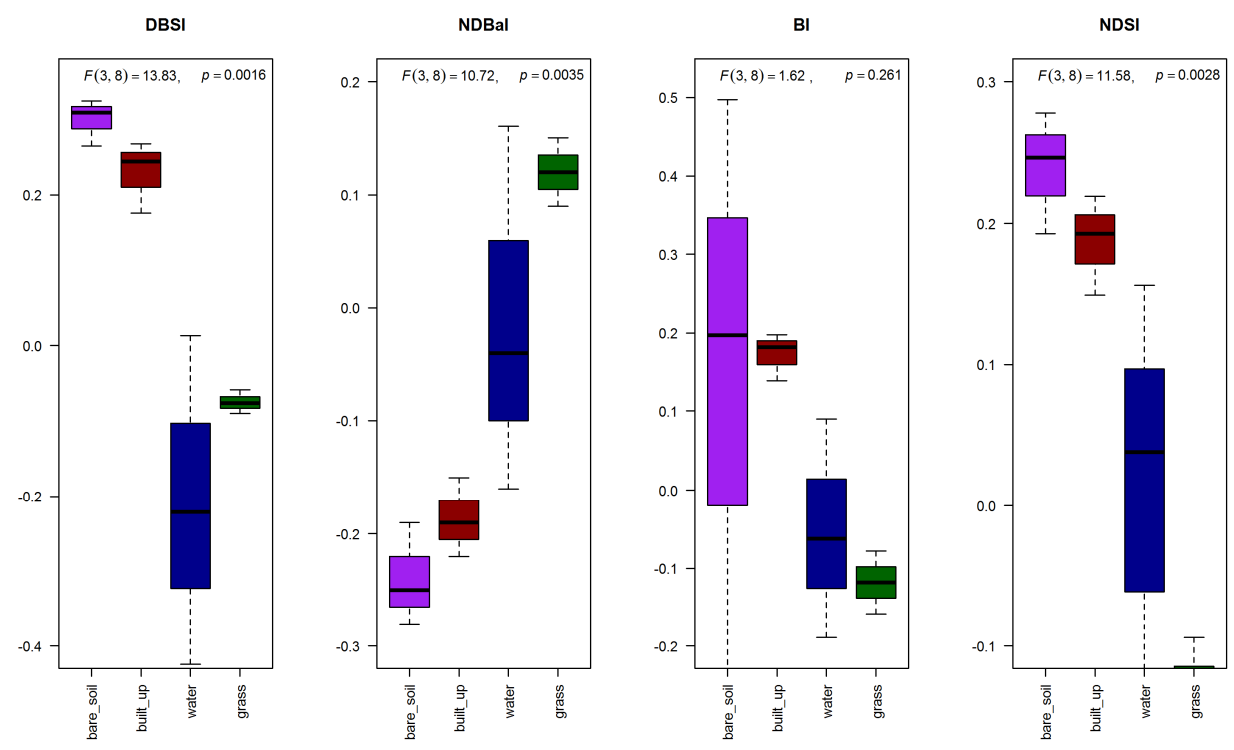

Figure 7. Comparison between DBSI, NDBaI, BI and NDSI for samples of four classes in the study area.

Table 2. Average and SD of DBSI, NDBaI, BI and NDSI of the city and $10 \mathrm{~km}$ buffer outside the city.

\begin{tabular}{cccccc}
\hline Indices & Mean (City) & SD (City) & Mean (10 km Buffer) & SD (10 km Buffer) & Difference (Buffer-City) \\
\hline DBSI & 0.23 & 0.056 & 0.28 & 0.039 & 0.05 \\
NDBaI & -0.19 & 0.052 & -0.21 & 0.039 & -0.02 \\
BI & 0.20 & 0.045 & 0.22 & 0.038 & 0.02 \\
NDSI & 0.20 & 0.050 & 0.21 & 0.043 & 0.01 \\
\hline
\end{tabular}

\subsection{Acurracy Assessment}

The results of the accuracy assessment show that the generated maps have an overall accuracy of $93 \%(\kappa=0.86)$ and $92 \%(\kappa=0.84)$ for DBI and DBSI, respectively (Tables 3 and 4$)$. A few pixels of bare rock in high and mountainous area are mixed with built-up areas due to their reflectance resembling the main building materials in this area. The results indicate that the proposed indices can be used reliably for differentiating constructed and bare land from other land use classes in arid and semi-arid climates.

Table 3. DBI accuracy assessment.

\begin{tabular}{cccccc}
\hline & Non-Built-Up & Built-Up & Classification Overall & $\begin{array}{c}\text { Producer Accuracy } \\
\text { (Precision) }\end{array}$ & $\begin{array}{c}\text { User Accuracy } \\
\text { (Recall) }\end{array}$ \\
\hline Non-built-up & 143 & 14 & 157 & $91.08 \%$ & $95.33 \%$ \\
Built-up & 7 & 136 & 143 & $95.1 \%$ & $90.67 \%$ \\
Truth overall & 150 & 150 & 300 & & \\
Overall Accuracy & $93 \%$ & & & & \\
K & 0.86 & & & & \\
\hline
\end{tabular}


Table 4. DBSI accuracy assessment.

\begin{tabular}{cccccc}
\hline & Non-Bare & Bare-Soil & Classification Overall & $\begin{array}{c}\text { Producer Accuracy } \\
\text { (Precision) }\end{array}$ & $\begin{array}{c}\text { User Accuracy } \\
\text { (Recall) }\end{array}$ \\
\hline Non-bare & 132 & 6 & 150 & $95.65 \%$ & $88 \%$ \\
Bare-soil & 18 & 144 & 150 & $88.89 \%$ & $96 \%$ \\
Truth overall & 150 & 150 & 300 & & \\
Overall Accuracy & $92 \%$ & & & & \\
K & 0.84 & & & & \\
\hline
\end{tabular}

\section{Discussion}

To distinguish urban areas and bare land using spectral indices is commonly associated with low accuracy due to the high degree of homogeneity [7]. Due to low moisture content in green areas surrounding cities, built-up and bare land indices that were developed for humid regions can often not sufficiently differentiate between built-up and bare land in drylands (Tables 1 and 2; Figures 5 and 6). In past studies, NDBI identified built-up areas accurately in cites in humid climates, for instance, in Colombo city in Sri Lanka [32], Montreal in Canada [30], São José dos Campos city in Brazil [23], Beijing and Guangzhou city in China [33,34]. In contrast, NDBI has performed poorly for mapping built-up areas in the semi-arid cities of Urumqi and Shihezi in western China [35,36]. Zhou et al. [21] also reported a low accuracy (57.4\%) of NDBI for Zhengzhou city in China from Landsat 8 OLI data.

Using Blue with TIR1 and SWIR1 with Green bands, the proposed DBI and DBSI techniques can map built-up and bare land in dry climate zones at an accuracy of $93 \%$ and $92 \%$, respectively. The results from DBI and DBSI are highly similar to land use classes from high-resolution satellite images. This result confirms that the proposed indices are able to detect built-up land from high DBI values and bare-soil land from high DBSI values. Applying the proposed indices in dry climate zones is shown to be more suitable. Thus, using the proposed indices for different backgrounds of urban areas may produce better and more accurate classification. This could be replicated in many fields of research, for example, in urban expansion and sustainability of cities.

Built-up areas have higher spectral values than bare land in the Blue band (Band 2), and in contrast, in the TIR1 band they have lower spectral values. The built-up index is accurate for distinguishing between land use/land cover classes using the TIR channels that display high emissivity in urban areas [7]. The main disadvantage of use thermal band is it has lower spatial resolution; however, because in Erbil and similar semi-arid areas, built-up areas generally exhibit higher values in the Blue and lower in the TIR band, it improves the accuracy of classification. Diminishing NDVI in the DBI and DBSI indices significantly improved accuracy of built-up mapping and addresses the ambiguity in areas with high NDVI (i.e., green areas) that are often confused with built-up areas [3,20,30]. Generally, high values of DBI and DBSI represent intense built-up and bare-soil, respectively, but the threshold to extract built-up areas and bare soil may vary between study sites.

\section{Conclusions}

Appropriate remotely sensed indicators of land use and land cover need to be defined for arid and semi-arid regions because these areas have different reflectance characters. As a consequence, indices developed for temperate regions may not give adequate results in dry climate areas. Since indices as NDBI and NDBaI are unable to distinguish between built-up areas and bare land that often surrounds cities in dry climates, this study proposes the application of two new spectral indices, DBI and DBSI derived from Landsat 8 data for mapping built-up and bare soil areas in dry climates.

The developed DBI and DBSI were applied to map urban areas and bare land in the city of Erbil, Iraq. The accuracy assessment shows an overall accuracy of $93 \%(\kappa=0.86)$ and $92 \%(\kappa=0.84)$ for DBI and DBSI, respectively. The results indicate that the proposed indices can be reliably used to differentiate built-up and bare land from other land use classes in arid and semi-arid climate. 
The suggested DBI index can separate only general built-up areas; it cannot separate finer urban cover types such as commercial and residential areas in detail. These indices focus on urban areas in dry climate, thus they may not be suitable for cities in humid regions or those surrounded by green spaces (positive NDVI). In this paper, the indices have demonstrated a potential for using Landsat 8 images to delineate between built-up areas and bare land within cities in dry climates. However, this study may have some limitations, thus more investigation into the application of different remote sensing imageries using these techniques in other study sites is required.

Author Contributions: Data curation, A.R.; Formal analysis, A.R.; Investigation, A.R.; Methodology, A.R.; Resources, A.R.; Supervision, H.B.; Validation, A.R.; Visualization, A.R.; Writing-original draft, A.R.; Writing-review \& editing, A.R., H.B., G.R.F.I., H.M.H., J.W., B.A., S.I., and P.M.N.

Funding: This research received no external funding.

Acknowledgments: Many thanks are extended to the USGS for providing the Landsat 8 image of the case study area, free of charge.

Conflicts of Interest: No potential conflict of interest was reported by the authors.

\section{References}

1. Zha, Y.; Gao, J.; Ni, S. Use of normalized difference built-up index in automatically mapping urban areas from TM imagery. Int. J. Remote Sens. 2003, 24, 583-594. [CrossRef]

2. Gallo, K.P.; Owen, T.W. Assessment of urban heat Islands: A multi-sensor perspective for the Dallas-Ft. worth, USA region. Geocarto Int. 1998, 13, 35-41. [CrossRef]

3. He, C.; Shi, P.; Xie, D.; Zhao, Y. Improving the normalized difference built-up index to map urban built-up areas using a semiautomatic segmentation approach. Remote Sens. Lett. 2010, 1, 213-221. [CrossRef]

4. Chen, X.-L.; Zhao, H.-M.; Li, P.-X.; Yin, Z.-Y. Remote sensing image-based analysis of the relationship between urban heat island and land use/cover changes. Remote Sens. Environ. 2006, 104, 133-146. [CrossRef]

5. Chen, W.; Liu, L.; Zhang, C.; Wang, J.; Wang, J.; Pan, Y. Monitoring the seasonal bare soil areas in Beijing using multitemporal TM images. In Proceedings of the 2004 IEEE International Geoscience and Remote Sensing Symposium (IGARSS'04), Anchorage, AK, USA, 20-24 September 2004.

6. Rogers, A.; Kearney, M. Reducing signature variability in unmixing coastal marsh Thematic Mapper scenes using spectral indices. Int. J. Remote Sens. 2004, 25, 2317-2335. [CrossRef]

7. As-Syakur, A.R.; Adnyana, I.W.S.; Arthana, I.W.; Nuarsa, I.W. Enhanced built-up and bareness index (EBBI) for mapping built-up and bare land in an urban area. Remote Sens. 2012, 4, 2957-2970. [CrossRef]

8. Li, H.; Wang, C.; Zhong, C.; Su, A.; Xiong, C.; Wang, J.; Liu, J. Mapping Urban Bare Land Automatically from Landsat Imagery with a Simple Index. Remote Sens. 2017, 9, 249. [CrossRef]

9. Zhang, Z.; Ji, M.; Shu, J.; Deng, Z.; Wu, Y. Surface urban heat island in Shanghai, China: Examining the relationship between land surface temperature and impervious surface fractions derived from Landsat ETM+ imagery. Int. Arch. Photogramm. Remote Sens. Spat. Inf. Sci. 2008, 37, 601-606.

10. Ji, M.; Jensen, J.R. Effectiveness of subpixel analysis in detecting and quantifying urban imperviousness from Landsat Thematic Mapper imagery. Geocarto Int. 1999, 14, 33-41. [CrossRef]

11. Flanagan, M.; Civco, D.L. Subpixel impervious surface mapping. In Proceedings of the 2001 ASPRS Annual Convention, St. Louis, MO, USA, 23-27 April 2001.

12. Lu, D.; Weng, Q. Use of impervious surface in urban land-use classification. Remote Sens. Environ. 2006, 102, 146-160. [CrossRef]

13. Kawamura, M.; Jayamana, S.; Tsujiko, Y. Relation between social and environmental conditions in Colombo Sri Lanka and the urban index estimated by satellite remote sensing data. Int. Arch. Photogramm. Remote Sens. 1996, 31, 321-326.

14. Fernando, T.; Gunawardena, A. Determination of Convertion of Tea Lands in Kandy District Using Different Remote Sensing Indices. Available online: https://www.researchgate.net/profile/Tamasha_Fernando/ publication/312377414_DETERMINATION_OF_CONVERSION_OF_TEA_LANDS_IN_KANDY_ DISTRICT_USING_DIFFERENT_REMOTE_SENSING_INDICES/links/587c855408ae9a860fecc313/ DETERMINATION-OF-CONVERSION-OF-TEA-LANDS-IN-KANDY-DISTRICT-USING-DIFFERENTREMOTE-SENSING-INDICES.pdf (accessed on 3 July 2018). 
15. Wu, C.; Murray, A.T. Estimating impervious surface distribution by spectral mixture analysis. Remote Sens. Environ. 2003, 84, 493-505. [CrossRef]

16. $\mathrm{Xu}, \mathrm{H}$. Analysis of impervious surface and its impact on urban heat environment using the normalized difference impervious surface index (NDISI). Photogramm. Eng. Remote Sens. 2010, 76, 557-565. [CrossRef]

17. Stathakis, D.; Perakis, K.; Savin, I. Efficient segmentation of urban areas by the VIBI. Int. J. Remote Sens. 2012, 33, 6361-6377. [CrossRef]

18. Deng, C.; Wu, C. BCI: A biophysical composition index for remote sensing of urban environments. Remote Sens. Environ. 2012, 127, 247-259. [CrossRef]

19. USGS. Landsat 8 Data Users Handbook; USGS: Reston, VA, USA, 2016.

20. Bhatti, S.S.; Tripathi, N.K. Built-up area extraction using Landsat 8 OLI imagery. GISci. Remote Sens. 2014, 51, 445-467. [CrossRef]

21. Zhou, Y.; Yang, G.; Wang, S.; Wang, L.; Wang, F.; Liu, X. A new index for mapping built-up and bare land areas from Landsat-8 OLI data. Remote Sens. Lett. 2014, 5, 862-871. [CrossRef]

22. Piyoosh, A.K.; Ghosh, S.K. Development of a modified bare soil and urban index for Landsat 8 satellite data. Geocarto Int. 2018, 33, 423-442. [CrossRef]

23. Ogashawara, I.; Bastos, V.D.S.B. A quantitative approach for analyzing the relationship between urban heat islands and land cover. Remote Sens. 2012, 4, 3596-3618. [CrossRef]

24. Rasul, A.; Balzter, H.; Smith, C. Applying a Normalized Ratio Scale Technique to Assess Influences of Urban Expansion on Land Surface Temperature of the Semi-Arid City of Erbil. Int. J. Remote Sens. 2017, 38, 3960-3980. [CrossRef]

25. NCCIRAQ, Erbil Governorate Profil. 2015. Available online: http://iomiraq.net/file/2224/download (accessed on 3 July 2018).

26. Najmaddin, P.M.; Whelan, M.J.; Balzter, H. Application of Satellite-Based Precipitation Estimates to Rainfall-Runoff Modelling in a Data-Scarce Semi-Arid Catchment. Climate 2017, 5, 32. [CrossRef]

27. Rasul, A.O. Remote Sensing of Surface Urban Cool and Heat Island Dynamics in Erbil, Iraq, between 1992 and 2013. Department of Geography. Ph.D. Thesis, University of Leicester, Leicester, UK, 2016.

28. Rasul, A.; Balzter, H.; Smith, C. Diurnal and seasonal variation of surface urban cool and heat islands in the semi-arid city of Erbil, Iraq. Climate 2016, 4, 42. [CrossRef]

29. USGS. Landsat Data; USGS: Reston, VA, USA, 2017.

30. Faisal, K.; Shaker, A.; Habbani, S. Modeling the Relationship between the Gross Domestic Product and Built-Up Area Using Remote Sensing and GIS Data: A Case Study of Seven Major Cities in Canada. ISPRS Int. J. Geo-Inform. 2016, 5, 23. [CrossRef]

31. $\mathrm{Xu}, \mathrm{H}$. Modification of normalised difference water index (NDWI) to enhance open water features in remotely sensed imagery. Int. J. Remote Sens. 2006, 27, 3025-3033. [CrossRef]

32. Ranagalage, M.; Estoque, R.C.; Murayama, Y. An urban heat island study of the Colombo metropolitan area, Sri Lanka, based on Landsat data (1997-2017). ISPRS Int. J. Geo-Inform. 2017, 6, 189. [CrossRef]

33. Liu, W.; Lu, L.; Ye, C.; Liu, Y. Relating urban surface temperature to surface characteristics in Beijing area of China. In Proceedings of the International Society for Optics and Photonics MIPPR 2009: Remote Sensing and GIS Data Processing and Other Applications, Yichang, China, 30 October-1 November 2009.

34. Xiong, Y.; Huang, S.; Chen, F.; Ye, H.; Wang, C.; Zhu, C. The impacts of rapid urbanization on the thermal environment: A remote sensing study of Guangzhou, South China. Remote Sens. 2012, 4, 2033-2056. [CrossRef]

35. Qian, J.; Zhou, Q.; Hou, Q. Comparison of pixel-based and object-oriented classification methods for extracting built-up areas in arid zone. In Proceedings of the ISPRS Workshop on Updating Geo-Spatial Databases with Imagery \& the 5th ISPRS Workshop on DMGISs, National Geomatics Center of China Sponsored, Urumchi, XingJiang, China, 28-29 August 2007.

36. Qian, J.; Zhou, Q.; Chen, X. Improvement of urban land use and land cover classification approach in arid areas. In Proceedings of the International Society for Optics and Photonics Image and Signal Processing for Remote Sensing XVI, Toulouse, France, 20-22 September 2010.

(C) 2018 by the authors. Licensee MDPI, Basel, Switzerland. This article is an open access article distributed under the terms and conditions of the Creative Commons Attribution (CC BY) license (http:/ / creativecommons.org/licenses/by/4.0/). 